\title{
爆破地震動観測資料による南関東の地殼構造
}

\author{
東京大学地震研究所 浅野周三・一ノ瀬洋一郎 \\ 地質調査所 長 谷 川 功 \\ 東海大学海洋学部 飯塚進 \\ 防災科学技術センター 鈴 木 宏 芳 \\ (昭和 53 年 12 月 18 日受理)
}

\section{Crustal Structure in the Southern Kanto District as Derived from Explosion Seismic Data}

\author{
Shuzo ASANO and Yoichiro ICHINOSE \\ Earthquake Research Institute, University of Tokyo \\ Isao HASEgAwa \\ Geological Survey of Japan \\ Susumu IIzUKA \\ Faculty of Marine Science and Technology, Tokai University \\ Hiroyoshi SUzuki \\ National Center for Disaster Prevention Research \\ (Received December 18, 1978)
}

In the southern Kanto district, the experiments to detect precursary change in velocity of seismic waves by means of explosion seismic method have been repeated under the earthquake prediction research project since 1968. These explosion seismic data supply good materials to obtain information on the crustal structure in the area although the distribution of observation sites is not suitable for the crustal studies. The shot points are Izu Oshima and Tateyama in the Boso Peninsula. Because of charge size and the distance of observation stations from the shot points, the information on the depth of the Mohorovičic discontinuity and Pn velocity could not be obtained.

The features of crustal structure derived from these data in addition to the existing explosion seismic data are as follows:

1) In the Boso Peninsula, thick surface layers with low velocities such as $2.5,4.5 \mathrm{~km} / \mathrm{s}$ are present above the layer with a velocity of $5.6 \mathrm{~km} / \mathrm{s}$.

2) Between Izu Oshima and the Boso Peninsula, there is a possibility to have a lateral change of structure. In this paper, it is assumed that this change takes place beneath the fault as indicated in the sea bottom topography, that is, the layer with a velocity of 5.6 $\mathrm{km} / \mathrm{s}$ on the east side contacts with the layer with a velocity of $6.0 \mathrm{~km} / \mathrm{s}$ beneath this place. 
3) Beneath the Boso Peninsula, the layer with a velocity of $5.6 \mathrm{~km} / \mathrm{s}$ exists directly above the layer with a velocity of $6.9 \mathrm{~km} / \mathrm{s}$, that is, the layer with a velocity of $6.0 \mathrm{~km} / \mathrm{s}$ is missing or very thin if exists.

4) Near Nagasa in the central part of southern Boso Peninsula, there is an offset in the upper boundaries of layers with a velocity of 5.6 and $6.9 \mathrm{~km} / \mathrm{s}$.

5) In the area of Izu Oshima and the Izu Peninsula, the layer with a velocity of 6.0 $\mathrm{km} / \mathrm{s}$ is shallow.

6) From both shot points, Izu Oshima and Tateyama, the layer with a velocity of 6.9 $\mathrm{km} / \mathrm{s}$ becomes shallower toward the Boso Peninsula and Dodaira, while it becomes deeper toward the Izu Peninsula.

7) Near Izu Oshima, the layer with a velocity of $6.9 \mathrm{~km} / \mathrm{s}$ becomes fairly shallower almost independent of the direction of profiles.

\section{$\S 1$. 序}

地震予知研究計画の下で地質調査所により伊豆大島で地震波速度変化の観測のための爆破が 1968 年 3 月に行なわれ現在も継続されている。また, 1971 年から 3 年間, 南関東の異常地殼 変動に関連して, 主として房総を含む地域の地震波速度変化の観測を目的として地震研究所に より千葉県館山市郊外で爆破が行なわれた。この爆破は伊豆大島の爆破の時期にあわせて行な われ，これらの爆破による地震動の観測は地質調査所，防災科学技術センタ一，東海大学，地 震研究所などの協同で行なわれ南関東に拈ける地震波速度変化の観測を強化した.これらの観 測資料は地殼構造を求めるのに用いることができる.

南関東，伊豆地域では爆破地震動研究グループによつて銚子爆破，河津・安中・紫雲寺爆破 による地震動の観測資料から地殼構造が得られている。河津・安中・紫雲寺測線では特に北部 でいわゆる立武岩質層, 約 $6.8 \mathrm{~km} / \mathrm{sec}$ の速度をもつた層が日本の爆破地震動観測で初めて得 られている〔堀田他 (1964)]。一方，中部地方をほぼ南北に横断する渥美・能登測線では玄武 岩質層が欠けるか，めつても極めて薄い構造が求められている[AoKI et al. (1972)]. もちろ ん,これらの測線はかなり離れており，その間に Fossa Magna が存在し，構造のかなりの変 化が予想される。しかし，大島，館山爆破の観測資料は伊豆から中部への資料を含んでおり， 大局的な構造の情報を与えるものであり，これが両測線の構造と大きく矛盾しないことが望ま しい，また，房総半島ではわが国で初めて地殼構造研究のために爆破孔を作孔して行なつた銚 子爆破による構造があり，1971年には，伊豆大島・館山爆破による地震動を房総南部で観測し て地壳構造を求めた〔爆破地震動研究グループ (1974)].

本論文では，地震波速度変化の研究，微小地震の震源決定などのために，地震波速度変化の 観測のために得られた資料, 爆破地震動研究グループの資料などから南関東の大局的な地殼構 造を求めた。 


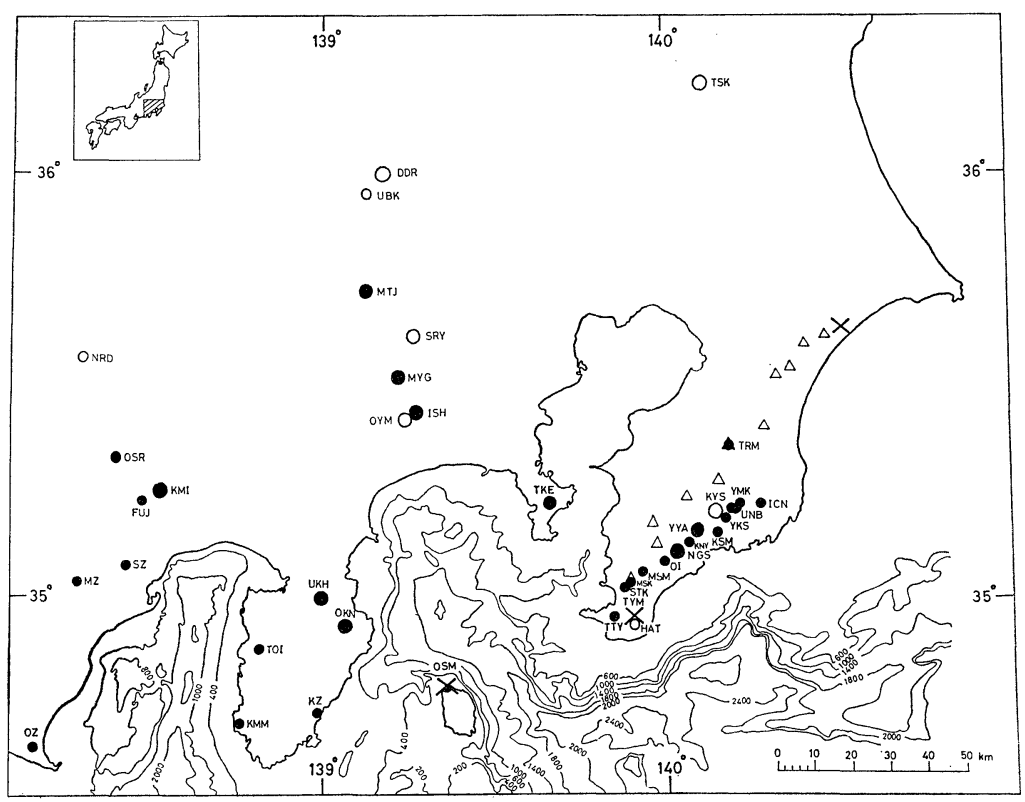

Fig. 1. Shot and observation points.

Cross mark: shot point. In addition to Oshima and Tateyama shot points, the shot point in Choshi profile is also shown.

Solid circle temporary stations for observation of change in velocity of seismic Small open circle $\}$ : waves.

Small solid circle: temporary observation stations for crustal studies. Those by Research Group for Explosion Seismology are also included.

Open circle: permanent stations of Dodaira Microearthquake Observatory.

Open triangle: observation stations in Choshi profile by Research Group for Explosion Seismology.

\section{$\S 2$. 観 測 資 料}

Fig. 1 には，大島・館山両爆破の爆破点，観測点を示してある．地震波速度変化の観測点 の他に, 爆破地震動研究グループによる房総の観測点, 銚子爆破の爆破点, 観測点; 地震研究 所堂平微小地震観測所の観測点, 富士川地殼变動観測所, その他の臨時観測点も示されている. 爆破は伊豆大島では $500 \mathrm{~kg}$ ，館山では $800 \mathrm{~kg}$ の火薬を 2 本の爆破孔につめて行なつた〔地震 波速度変化研究グループ (1975)，浅野周三他（1976)]. 伊豆大島からは北東方向（房総方向）, 北方向 (大山，堂平方向), 北西方向（伊豆方向）に観測点が存在し，館山からも，ほぼ 3 方 向に並んでいる. Table 1 には観測点の緯度, 経度, 高度が示されている. 爆破地震動研究グ ループの観測点などの資料については省略してある.

この実験は，元来，地震波速度变化をみるために実施されたので，大部分の記録は良好であ る. 爆破が毎年繰返して行なわれ，記録の再現性がよいので，或る年の記録が悪くても他の年 
Table 1. Coordinates of shot and observation points for Oshima and Tateyama explosions

\begin{tabular}{|c|c|c|c|c|}
\hline $\begin{array}{l}\text { Observation } \\
\text { point }\end{array}$ & Station code & Longitude & Latitude & Elevation \\
\hline Oshima* & & $139^{\circ} 21^{\prime} 56^{\prime \prime} \mathrm{E}$ & $34^{\circ} 47^{\prime} 40^{\prime \prime} \mathrm{N}$ & $\langle 5 \mathrm{~m}$ \\
\hline Tateyama* & & 1395434 & 345644 & 110 \\
\hline Okuno & $\mathrm{OKN}$ & 1390414 & 345555 & 140 \\
\hline Ukihashi & UKH & 1385959 & 350102 & 230 \\
\hline Fujigawa & FUJ & $138 \quad 2819$ & 351354 & 125 \\
\hline Oshiro & OSR & 1382301 & 351939 & 500 \\
\hline Kamiinako & KMI & 1383158 & 351548 & 210 \\
\hline Narada & NRD & 1381810 & 353400 & 750 \\
\hline Isehara & ISH & 1391606 & 352610 & 260 \\
\hline Miyagase & MYG & 1391349 & 353102 & 300 \\
\hline Motojuku & MTJ & 1390843 & 354342 & 420 \\
\hline Ubukawa & UBK & 1390646 & $35 \quad 5718$ & 520 \\
\hline Takeyama & TKE & 1394001 & 351301 & 112 \\
\hline Tateyama & TTY & 1395053 & 345815 & $\sim 30$ \\
\hline Hata & HAT & 1395432 & 345608 & 110 \\
\hline Masaki & MSK & 1395230 & 350127 & $\sim 20$ \\
\hline Shimotakita & STK & 1395418 & 350249 & 50 \\
\hline Masuma & MSM & 1395525 & 350337 & 70 \\
\hline $\mathrm{Oi}$ & OI & 1395951 & 350536 & 30 \\
\hline Nagasa & NGS & 1400159 & 350631 & 140 \\
\hline Yuya & YYA & 1400615 & 350814 & 30 \\
\hline Tsurumai & TRM & 1401117 & 352225 & 80 \\
\hline Oshima & OSM & $1392156 * *$ & $344740 * *$ & $<5$ \\
\hline Oyama $^{+}$ & OYM & 1391435 & 352512 & 600 \\
\hline Shiroyama $^{+}$ & SRY & 1391627 & 353630 & 254 \\
\hline Dodaira $^{+}$ & $\mathrm{DDR}$ & 1391136 & 355954 & 800 \\
\hline Tsukuba ${ }^{+}$ & TSK & 1400635 & 361239 & 280 \\
\hline Kiyosumi $^{+}$ & KYS & 1400854 & 351152 & 180 \\
\hline
\end{tabular}

* Shot point.

**The coordinates of the shot point are used since the difference of distance is not significant.

+ These belong to Dodaira Microearthquake Observatory, Earthquake Research Institute, University of Tokyo.

の良い記録を用いることができ，かつ，初動部分を重ね合わせることによつて読み取りの信頼 度を高めることができる，従つて初動の読み取り精度は極めてよい．ただし，爆破方法と爆破 点の地質によると推測されるが，相対的に大島爆破による地震動は，館山爆破に比べて数倍大 きく, SN 比にも影響している. Table 2 飞は走時表が与兄られている. Figs. 2, 3 飞は, それぞれ大島, 館山爆破の地震波速度变化観測の観測点より得られた record section を示す.

\section{§3. 地款 構 造}

Table 2 に示された大島, 館山両爆破の観測資料; 爆破地震動研究グループによる銚子爆破, 大島，館山爆破の観測資料を用いて，南関東の地殼構造を求める. 
Table 2. Travel time data in Oshima and Tateyama explosions

\begin{tabular}{|c|c|c|c|c|c|c|}
\hline \multirow{2}{*}{$\begin{array}{l}\text { Observation } \\
\text { point }\end{array}$} & \multicolumn{3}{|c|}{ Oshima explosion } & \multicolumn{3}{|c|}{ Tateyama explosion } \\
\hline & Distance & $P-O^{*}$ & $P-O-4 / 6$ & Distance & $P-O$ & $P-O-4 / 6$ \\
\hline $\mathrm{OKN}$ & $31.06 \mathrm{~km}$ & $6.41^{\mathrm{s}}+\mathrm{A}^{* *}$ & $1.23^{\mathrm{s}}$ & $76.66 \mathrm{~km}$ & $14.62^{s}+B$ & $1.84^{\mathrm{s}}$ \\
\hline UKH & 41.69 & $8.27+\mathrm{A}$ & 1.32 & 83.45 & $\lceil 15.81-$ & $\lceil 1.90$ \\
\hline FUJ & 94.91 & $17.18+\mathrm{D}$ & 1.36 & - & - & - \\
\hline OSR & 107.35 & $18.93+\mathrm{C}$ & 1.04 & - & - & - \\
\hline KMI & 92.11 & $16.38+\mathrm{A}$ & 1.03 & 130.38 & $22.84+B$ & 1.11 \\
\hline NRD & 129.28 & $\lceil 22.22+$ & $\ulcorner 0.67$ & - & - & - \\
\hline ISH & 71.89 & $13.67+\mathrm{A}$ & 1.69 & 79.83 & $\begin{array}{l}16.14+\mathrm{D} \\
\lceil 16.27-\end{array}$ & $\begin{array}{r}2.83 \\
\lceil 2.96\end{array}$ \\
\hline MYG & 81.31 & $14.94+\mathrm{A}$ & 1.39 & 88.58 & $\lceil 17.28-$ & $\lceil 2.52$ \\
\hline MTJ & 105.58 & $18.26+\mathrm{B}$ & 0.66 & 111.36 & $20.26+\mathrm{C}$ & 1.70 \\
\hline UBK & $130: 80$ & $22.30+B$ & 0.50 & - & - & - \\
\hline TKE & 54.36 & $11.84+\mathrm{B}$ & 2.78 & 37.37 & $10.46+\mathrm{C}$ & 4.23 \\
\hline TTY & 48.26 & 10.43 & 2.39 & - & - & - \\
\hline HAT & 52.09 & $11.19+\mathrm{B}$ & 2.51 & - & - & - \\
\hline MSK & 53.17 & $11.43-\mathrm{B}$ & 2.57 & - & - & - \\
\hline STK & 56.68 & $12.20+\mathrm{B}$ & 2.75 & 11.23 & $4.44+\mathrm{A}$ & 2.57 \\
\hline MSM & 59.01 & $12.58+\mathrm{A}$ & 2.74 & - & - & - \\
\hline OI & - & - & - & 18.27 & $6.13+B$ & 3.08 \\
\hline NGS & 70.37 & $13.91+\mathrm{A}$ & 2.18 & 21.33 & $6.92+\mathrm{A}$ & 3.36 \\
\hline YYA & 77.43 & $\begin{array}{l}14.63+\mathrm{D} \\
\lceil 14.76-\end{array}$ & $\begin{array}{r}1.72 \\
\lceil 1.85\end{array}$ & 27.61 & $8.27+\mathrm{A}$ & 3.67 \\
\hline TRM & 98.77 & $\lceil 18.32+$ & $\lceil 1.86$ & 53.85 & $\begin{array}{l}13.01+\mathrm{D} \\
\lceil 13.73-\end{array}$ & $\begin{array}{r}4.03 \\
\lceil 4.75\end{array}$ \\
\hline OSM & - & - & - & 52.47 & $11.46+\mathrm{B}$ & 2.72 \\
\hline OYM & 70.31 & $13.49+\mathrm{A}$ & 1.77 & 80.36 & $16.25+C$ & 2.86 \\
\hline SRY & 90.68 & $16.42+\mathrm{B}$ & 1.31 & 93.54 & $18.87+\mathrm{D}$ & 3.28 \\
\hline $\mathrm{DDR}$ & 134.49 & $\lceil 22.86-$ & $\ulcorner 0.44$ & 133.67 & $\ulcorner 23.50+$ & $\lceil 1.21$ \\
\hline TSK & 171.04 & $\lceil 27.50+$ & $\Gamma-1.01$ & 141.56 & $\lceil 25.16+$ & $\lceil 1.51$ \\
\hline KYS & 84.30 & $15.80-\mathrm{D}$ & 1.75 & 35.46 & $9.92-\mathrm{C}$ & 4.01 \\
\hline
\end{tabular}

* $O$ : Shot time

** $6.41^{\mathrm{s}}+\mathrm{A}$ means that the travel time is $6.41^{\mathrm{s}}$, the direction of ground motion at the onset is upward and the rank of identification is A. Identification of first arrivals is classified by taking clarity of onset and time accuracy into account as follows:

A: very clear, B: clear, C: fairly clear, D: accuracy of identification worse than 0.1 sec or doubtful onset.

The mark $\Gamma$ shows that signals are recognized after this time, that is, signals must arrive earlier than this time.

\section{房総方向}

先ず, 房総半島の構造を求めるために, 館山, 銚子爆破の資料を正逆測線の資料として用い る. Fig. 1 に示されるように, この 2 測線は, ほぼ平行であるが約 $10 \mathrm{~km}$ 離れており厳密に は正逆測線ではない。しかし房総の地質構造の走向がほぼ東西で，2測線が注汸同じ角度で走 つているので, 対応する走時曲線を組合せて真の速度を求めても大きな誤差が生ずるとは考え 

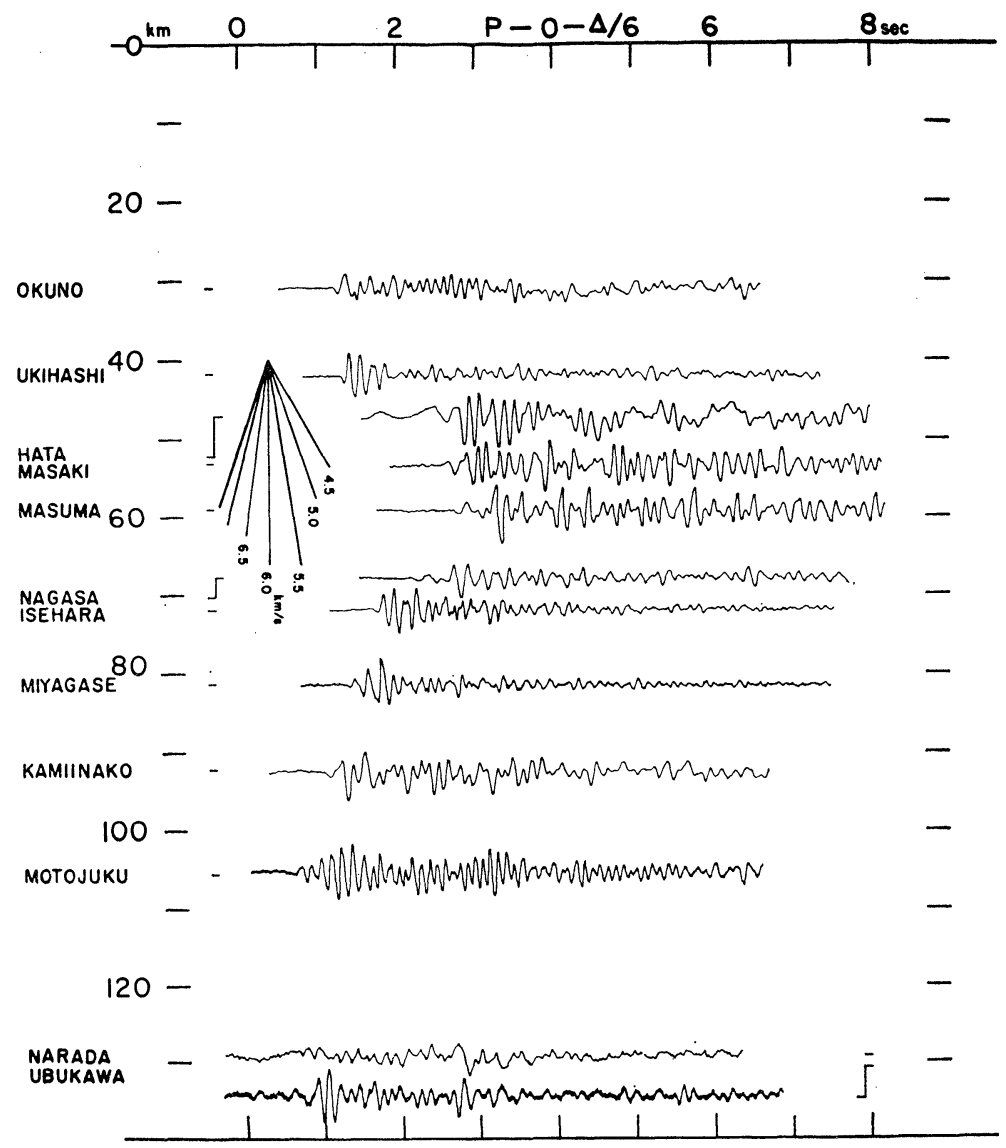

Fig. 2. Record section obtained at temporary observation stations in Oshima explosion.

られない．Fig. 4 は館山および銚子爆破の資料による走時図である．銚子爆破の資料からは， 爆破地震動研究グループによつて表層付近を除いて $4.88,5.60 \mathrm{~km} / \mathrm{s}$ の速度が得られている が，ここでは，これにとらわれず，館山爆破の走時図を考慮してひいた走時曲線が Fig. 4 に は示され走時の式は次の通りである.

館山爆破

$$
\begin{aligned}
& T_{1}(\mathrm{~s})=1.88+\Delta(\mathrm{km}) / 4.32 \\
& T_{2}(\mathrm{~s})=3.37+\Delta(\mathrm{km}) / 5.56
\end{aligned}
$$

銚子爆破

$$
\begin{aligned}
& T_{1}{ }^{\prime}=1.32+\Delta(\mathrm{km}) / 4.61 \\
& T_{2}{ }^{\prime}=2.45+\Delta(\mathrm{km}) / 5.65
\end{aligned}
$$

この館山爆破の走時を解釈するに際し，大島爆破の走時も参照している。すなわち，直線から のずれが大きい観測点は，大島・館山両爆破でずれがほぼ同じになるように走時の線をひいた。 上述したように館山, 銚子爆破は正逆測線となつていないので, 上の走時式の reverse point は合わせていない，館山に拈るる各層への深さと層の傾き，真の速度を得るために，上式を用 


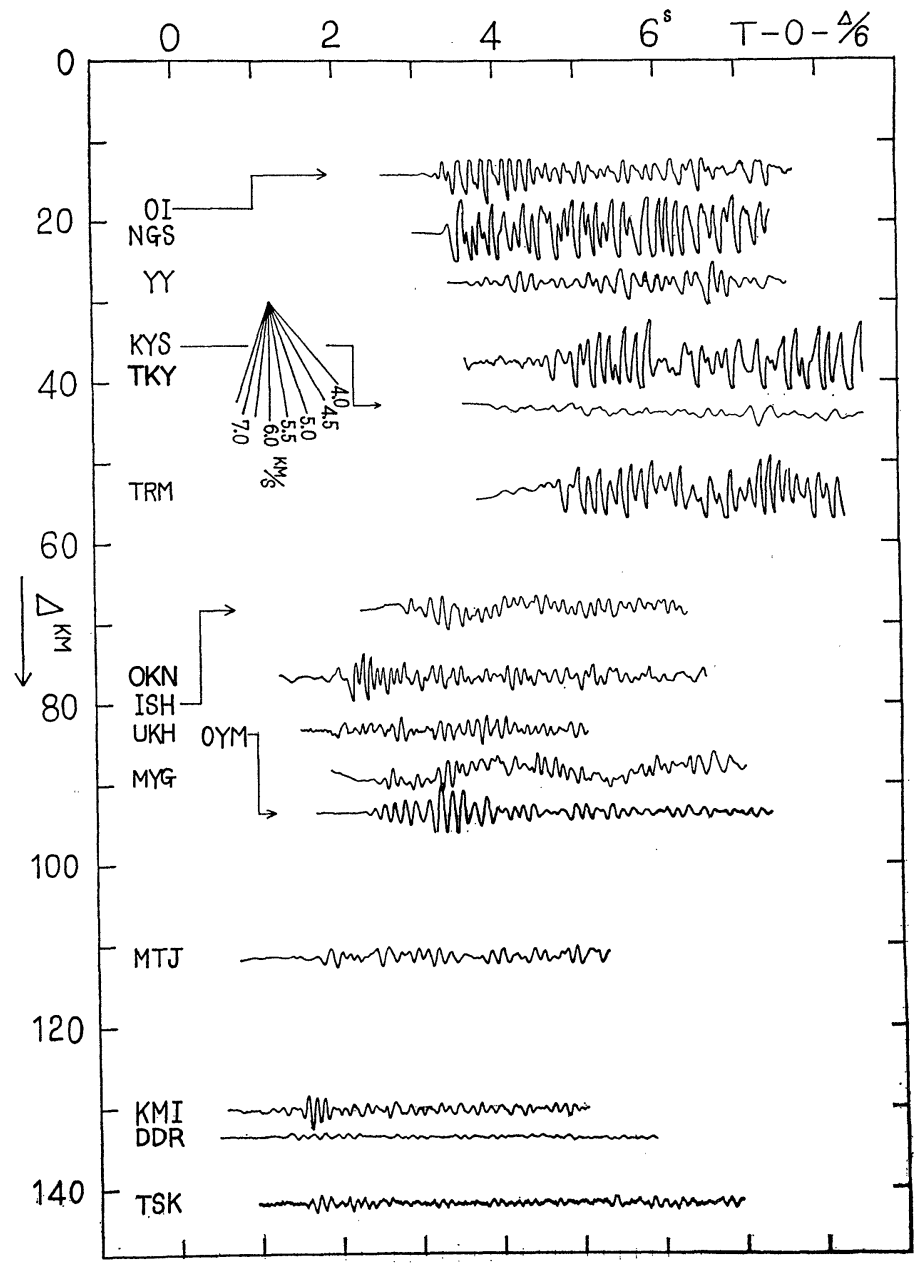

Fig. 3. Record section obtained at temporary observation stations in Tateyama explosion.

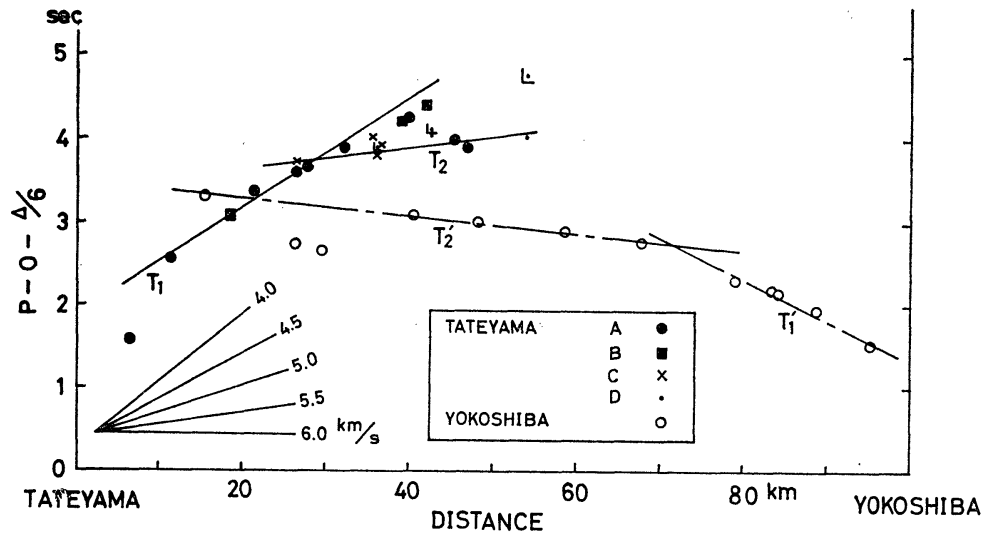

Fig. 4. Reduced travel time plot for Tateyama-Choshi (Yokoshiba) profile.

Identification of first arrivals in Tateyama explosion is classified by taking clarity of onset and time accuracy into account as follows:

A: very clear, B: clear, C: fairly clear, D: accuracy of identification worse than 0.1 sec or doubtful onset.

L.: Signals are recognized after this plot, that is, the first arrival is expected to be present earlier than this plot. 


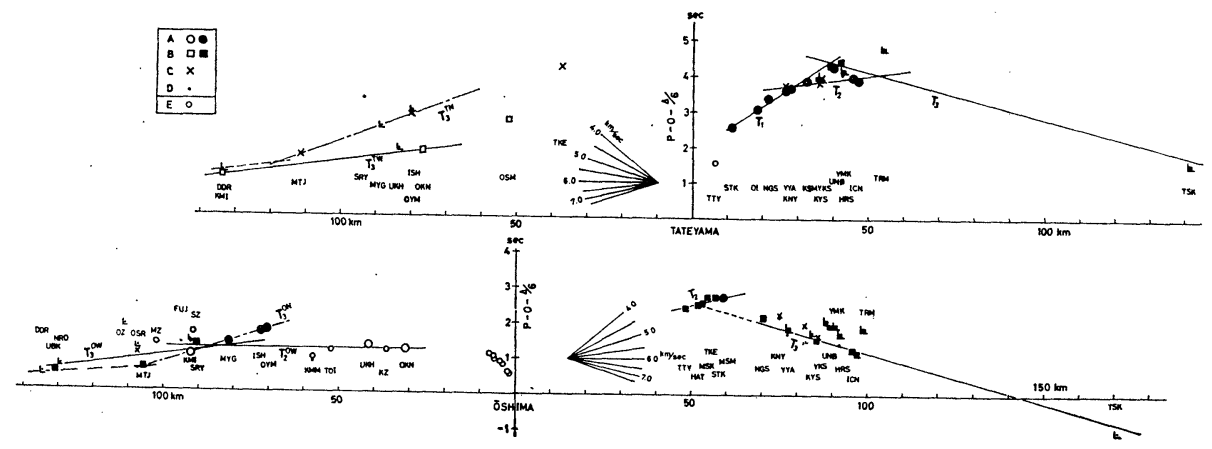

Fig. 5. Reduced travel time plot for Oshima and Tateyama explosions.

Classification in identification of first arrivals except for $\mathrm{E}$ is the same as given in the caption of Fig. 4. Data designated by $\mathrm{E}$ means those derived from observation by other scientists. On the lefthand side of each shot, open marks show data along OshimaIzu Peninsula profile and solid marks show those along Oshima-Dodaira profile.

いると，館山での第 2 層の厚さ： $2.84 \mathrm{~km}$ ，第 2 層の上面の傾斜： $-1.26^{\circ}$ ，第 2 層の真の速 度： $4.46 \mathrm{~km} / \mathrm{s}$ ，第 3 層の厚さ： $4.95 \mathrm{~km}$, 第 3 層の上面の傾斜： $1.46^{\circ}$ ，第 3 層の真の速度：

$5.60 \mathrm{~km} / \mathrm{s}$ と求まる.

房総に拈ける第 3 層より深部の情報は，館山爆破では不十分で，大島爆破の房総に扣ける観 測資料より得られる．Fig. 1 にみられるように，館山爆破の爆破点は大島爆破の測線より南 にずれて括り，地震波が同じ構造を通つていない恐れもあるが，現在は資料がないので，一様 として解析した．Fig. 5 には館山，大島爆破の走時図が爆破点で観測点を東西に分けて示さ れている. Fig. 5 より大島爆破の房総に怙ける走時は, fluctuation が大きく, かなり複雑 なことがわかる．前述したように，2つの爆破の走時の fluctuation の相関がかなりよいので， 表層の effect と考光，図に示されるような直線をひいた。この直線は

$$
T_{3}=4.00+\Delta / 7.20
$$

となる。 $T_{3}$ が初動として現われるのは $60 \sim 70 \mathrm{~km}$ の距離であり, 極めて近くから $7 \mathrm{~km} / \mathrm{s}$ を こえる見掛速度が得られ南関東の地殼構造の特徵を示している.

館山 (TTY) 一増間 (MSM) の近距離の点は

$$
T_{2}=1.25+\Delta / 5.22
$$

の線にのる。 $T_{2}, T_{3}$ の間には $0.4 \mathrm{~s}$ 近い offset があり, 構造の offset の存在が推測され る.

大島爆破の $T_{3}$ を参照して館山爆破の筑波の観測をみると，筑波では他の観測点より速いこ とを考慮して $T_{3}$ をひくことは可能である．この $T_{3}$ がぞの層によるかは問題である。いわゆ る花崗岩質層の傾斜によるとすれば傾斜が大きくなり上層にぶつかるといら不都合を生ずる. 
従つて房総では $6 \mathrm{~km} / \mathrm{s}$ の層が欠けているか, あつてもかなり薄い, そして $5.6 \mathrm{~km} / \mathrm{s}$ 層の下 に $6.8 \mathrm{~km} / \mathrm{s}$ 前後の速度の玄武岩質層が存在し $T_{3}$ の見掛速度を与えると考兊ざるを得ない. そこで他の方向で $6 \mathrm{~km} / \mathrm{s}$ の見掛速度が出ていないかと Fig. 5 をみると，大島爆破の西方， 奥野 $(\mathrm{OKN})$, 浮橋 $(\mathrm{UKH})$ などの資料が $6 \mathrm{~km} / \mathrm{s}$ の見掛速度を与える. 大島爆破では，大島 で田中ら（1969）の観測があり，その資料と今回の資料を組合せると大島から伊豆へかけての 構造が求められる. 表層の速度は $2.0 \mathrm{~km} / \mathrm{s}$ として

$$
\begin{aligned}
& T_{1}^{\text {ow }}=0.48+\Delta / 3.91 \\
& T_{2}^{\text {ow }}=1.25+\Delta / 6.00
\end{aligned}
$$

なる観測より得られた走時をもとに, 平行層の仮定で大島での厚さを求めると $2.0 \mathrm{~km} / \mathrm{s}$ 層が $0.56 \mathrm{~km}, 3.91 \mathrm{~km} / \mathrm{s}$ 層が $1.86 \mathrm{~km}$ となる.

上述のように房総半島南部では $5.6 \mathrm{~km} / \mathrm{s}$ 層の下に玄武岩質層が直接存在するとみなす方がよ い.この玄武岩質層の速度は今回の資料からは余りよく求められないが，仮に大島西方 (OKN 一KMI) と大島東方（房総方面）の測線を split profile とみなすと $6.9 \mathrm{~km} / \mathrm{s}$ の速度が得ら れる.この值は, 紫雲寺, 河津爆破〔堀田他 (1964)〕で得られた $6.8 \mathrm{~km} / \mathrm{s}$ に近い. 房総で の玄武岩質層の傾斜を余り大きくしないためにも，大きい值が都合がよいので，本論文では一 様に $6.9 \mathrm{~km} / \mathrm{s}$ とした. 走時の式

$$
T_{3}=5.43+\Delta / 7.17
$$

より傾斜は $3.46^{\circ}$ となる。 また，仮に館山，銚子爆破よりの浅部構造が存在するとすれば, $6.9 \mathrm{~km} / \mathrm{s}$ 層の上面の館山に护矿深さは $15.43 \mathrm{~km}$ と求められる.

大島爆破の房総に打ける観測で， $T_{2}, T_{3}$ の間に存在する offset は $5.6 \mathrm{~km} / \mathrm{s}$ 層と $6.9 \mathrm{~km} / \mathrm{s}$ 層の上面に存在する offset によるとした。 offset を2 層に分けたのは，一方だけにすると offset が大きくなりすぎ，層が pinch out するからにすぎない。

以上のように走時図から推定されることを出発点として大島, 館山爆破の房総に和ける観測 を説明するために，大島から房総へかけての構造を求めると Fig. 6 のよらになる． O-C は 大部分 $0.1 \mathrm{~s}$ 以内である.このモデルの特徵を要約すると, 館山付近では $5.6 \mathrm{~km} / \mathrm{s}$ 層の上に,

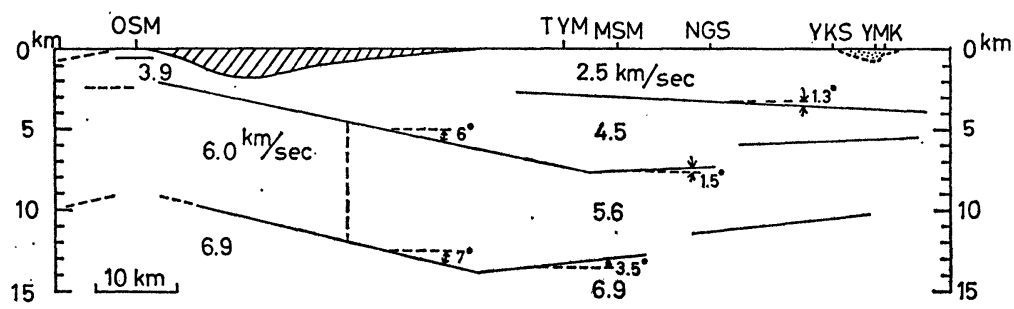

Fig. 6. Crustal structure derived for Oshima-Boso Peninsula profile. 
$2.5,4.5 \mathrm{~km} / \mathrm{s}$ の速度をもつ層がかなり厚く存在すること, $6.9 \mathrm{~km} / \mathrm{s}$ 層は館山付近で最も深 くなり (約 $14 \mathrm{~km})$, 大島方向, 東方に向つて浅くなる, 特に大島へ向つては浅くなる（大島

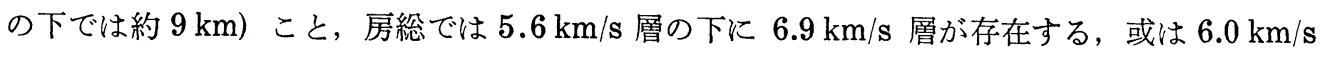
層が欠けていること, $5.6 \mathrm{~km} / \mathrm{s}$ 層は相模湾の断層的な海底地形の下付近で $6.0 \mathrm{~km} / \mathrm{s}$ 層と接し ていること（これは断層的な海底地形を考慮したものであるが，十分な観測資料はない)， 5.6 $\mathrm{km} / \mathrm{s}$ 層, $6.9 \mathrm{~km} / \mathrm{s}$ 層の上面が長狭 (NGS) 付近で約 $1 \mathrm{~km}$ 浅くなつていることなどである. なお，館山爆破では地震波の通る経路が大島爆破の時と異るので，館山爆破の資料のみより考 えると, 館山爆破の測線方向では $6.9 \mathrm{~km} / \mathrm{s}$ 層の上の境界面の offset はやや大きく, かつ, 館 山の爆破点へむけて境界面が深くなる傾向がある。 また，横瀬 (YKS), 市の郷 (ICN) の間 には地表面に $2.5 \mathrm{~km} / \mathrm{s}$ より低速度の層が図示されているように存在すると考兄られる.

房総半島の地質は, ほぼ東西の走向をもつているが, 観測点, 爆破点の密度が十分でないの で表面地質との対応はよくない。しかし，長狭付近には嶺岡層という玄武岩を主とする地層が 露出しているので, 長狭付近で $5.6 \mathrm{~km} / \mathrm{s}$ 層, $6.9 \mathrm{~km} / \mathrm{s}$ 層に offset が存在することと対応し ているといえる.

\section{伊豆方向, 大山・堂平方向}

次に大島, 館山爆破の伊豆方向, 大山 (OYM) - 堂平 (DDR) 方向の構造を求める. Fig. 1, Fig. 5 より，この方では近距離の観測がほとんどないので，大局的な構造が求まれば十分 である.この方向でも, 大島, 館山爆破による地震波は異る所を通るが，本論文では類似の構 造になるようにした．Fig. 5 で特徵的なことは，爆破点にかかわらず，大山・堂平方向には $7.4 \mathrm{~km} / \mathrm{s}$ 以上, 伊豆方向には約 $6.5 \mathrm{~km} / \mathrm{s}$ の見掛速度がみられ, $6.9 \mathrm{~km} / \mathrm{s}$ 層の上面の傾きが 類似していることである.大島爆破の方が観測点の配置がよく記録もよいこと, 奥野 $(\mathrm{OKN})$, 浮橋 $(\mathrm{UKH})$ で $6 \mathrm{~km} / \mathrm{s}$ の見掛速度が出ていることなどの理由から, 先に大島爆破の資料を 用いて構造を求める。

先ず, 北部 (大山・堂平) 方向では, 大島直下では $2.0,3.91,6.0 \mathrm{~km} / \mathrm{s}$ の層が平方層之 して存在するとして

$$
T_{3}^{\mathrm{ON}}=4.00+\Delta / 7.43
$$

の線がひけるので，真の速度を $6.9 \mathrm{~km} / \mathrm{s}$ として傾斜を求めると $6.55^{\circ}$ になる．大山・堂平 間の観測点は関東山地に存在し，表層の低速度の層はないか，薄いと考学られるので，過去の 測線の結果を参照して単に $5.5 \mathrm{~km} / \mathrm{s}$ 層が $4 \mathrm{~km}$ の厚さで一様に存在すると仮定した．遠方の 本宿 $(\mathrm{MTJ})$, 生川 (UBK), 堂平 (DDR) は $6.27 \mathrm{~km} / \mathrm{s}$ の見掛速度を与えるが, $12.7^{\circ}$ の傾 斜で $6.9 \mathrm{~km} / \mathrm{s}$ 層が深くなつているためと解釈した。一点だけではあるが館山爆破においても 

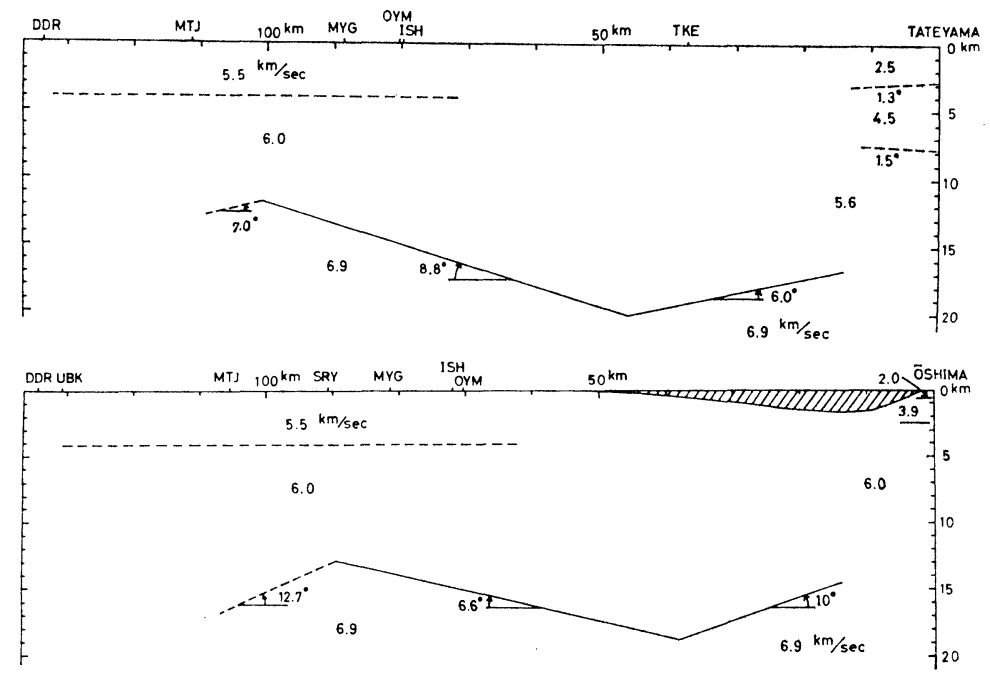

Fig. 7. Crustal structure in Oshima-Dodaira profile (the lower figure) and in TateyamaDodaira profile (the upper one).

堂平は同じ傾向を示している．Fig．７下図には観測值を説明するためのモデルの例を示した. このモデルでも大島へ向つて $6.9 \mathrm{~km} / \mathrm{s}$ の上の境界面がかなり急激（モデルでは $10^{\circ}$ とした が，他の方向の傾向からみて大島の近くでは更に急に浅くなる）に浅くなつている，また， $6.9 \mathrm{~km} / \mathrm{s}$ 層が北に深くなる傾向は $139^{\circ} \mathrm{E}$ に沿う測線で求められた構造〔堀田他 (1964)]の 傾向と類似している。

次に，館山爆破による大山・堂平間の構造を，上に求めた大島爆破による構造と調和するよ うに求める. Fig. 5 に示されるように, 伊勢原 (ISH), 大山 (OYM), 宮ヶ瀬 (MYG), 本 宿 (MTJ) の走時は

$$
T_{3}^{\mathrm{TN}}=5.78+\Delta / 7.69
$$

なる線を与える，館山爆破点下の構造は，北東方向の構造と同じとして，上の見掛速度を 6.9 $\mathrm{km} / \mathrm{s}$ 層が与えるための傾斜は $8.76^{\circ}$ となる。この傾斜では館山での深さが大きくなりすぎる， 館山で浅くすると遠方では浅くなりすぎるという不都合を生ずるので，他の方向の館山の下の 深さを考虑して途中から $6^{\circ}$ の傾斜で館山へ向つて浅くなるとして観測值を説明した. $6.9 \mathrm{~km} / \mathrm{s}$ 層が最も深くなるのは距離約 $50 \mathrm{~km}$ の下であり $20 \mathrm{~km}$ に達する. 前述のように堂平 (DDR) は. $T_{3}^{\mathrm{TN}}$ の線より扔くれるが，大島測線と同じ傾向である。仮に $6.5 \mathrm{~km} / \mathrm{s}$ の線に堂平がのつ ているとすると $6.9 \mathrm{~km} / \mathrm{s}$ 層の傾斜は $7.0^{\circ}$ と求まる. 大山・堂平の $6.9 \mathrm{~km} / \mathrm{s}$ 層の傾斜は $8.8^{\circ}$ と求められ, 大島爆破からは $6.6^{\circ}$ と求めら礼たが, この差は測線の位置の違いと考光 られる．館山方向の構造の傾斜が急であるのは基盤の傾向からも想像される。また，武山 

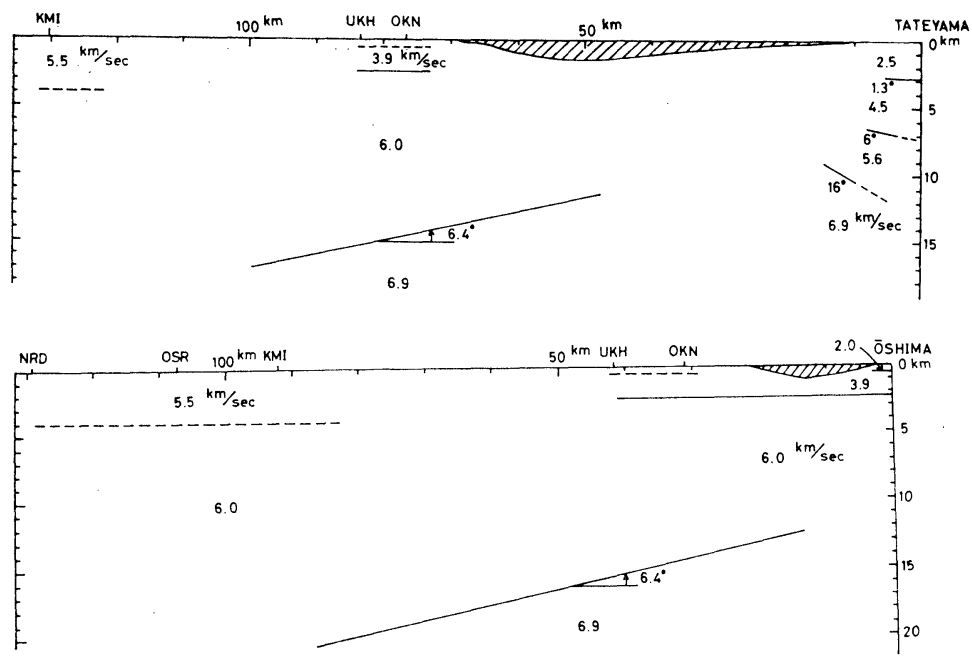

Fig. 8. Crustal structure in Oshima-Izu Peninsula profile (the lower figure) and in TateyamaIzu Peninsula profile (the upper one).

(TKE) は館山爆破の正木 (MSK), 増間 (MSM) 方向と同様の構造で説明されるが，表面に 低速度の層の存在が推定される。

次に大島から伊豆方向へかけての構造を求める。すでに述べた $T_{1}^{\mathrm{ow}}, T_{2}^{\mathrm{ow}}$ に加えて Fig. 5 の走時図に示されるように

$$
T_{3}^{\mathrm{oW}}=2.37+\Delta / 6.53
$$

なる線がひける． $6.93 \mathrm{~km} / \mathrm{s}$ 層の傾さによるとすると $6.35^{\circ}$ と求まる．奥野, 浮橋の浅部構 造には大島とこの 2 点によるものをそのまま仮定し，上稲子 (KMI)，大城 (OSR)，奈良田 (NRD) の浅部構造には，堂平方向と同様， $5.5 \mathrm{~km} / \mathrm{s}$ 層が $4 \mathrm{~km}$ の厚さで存在すると仮定した. 走時を説明する構造の 1 つのモデルを示すと Fig. 8 の下図のようになる. $6.9 \mathrm{~km} / \mathrm{s}$ 層の上 面は奥野，浮橋付近で約 $15 \mathrm{~km}$ の深さ，上稲子付近で $20 \mathrm{~km}$ をこ学る．糸魚川・静岡構造線 が存在するが，この傾向は $139^{\circ} \mathrm{E}$ 線に沿う測線下の構造, 渥美・能登測線の構造 (玄武岩質層 がうすい)の傾向と定性的に一致する. $139^{\circ} \mathrm{E}$ 線に沿う測線の構造と比べると浅いが, $6.9 \mathrm{~km} / \mathrm{s}$ 層の上面に関しては, $139^{\circ} \mathrm{E}$ 線の測線の南の端に近く，この差は余り問題にならないと考えら れる.

次に館山爆破による上稲子方面の構造について述べる．Fig. 5 に示されるように，奥野， 浮橋, 上稲子の走時は

$$
T_{3}^{\mathrm{TW}}=2.88+\Delta / 6.52
$$

なる直線にのる. 見掛速度は大島爆破のこの方向の值と同じなので, $6.9 \mathrm{~km} / \mathrm{s}$ 層上面の傾斜 
$6.35^{\circ}$ で説明できる. 観測点下の浅部構造は大島爆破の測線下で仮定したものを，爆破点下の それは, 館山付近のものを仮定し, 奥野, 浮橋の下での $6.9 \mathrm{~km} / \mathrm{s}$ 層の上面の深さがほぼ同じ になるようにして構造を求めると，Fig.8の上図に示されるようになる．観測走時を説明する ためには，館山爆破点付近の $6.9 \mathrm{~km} / \mathrm{s}$ 層の上面の傾きを $16^{\circ}$ とかなり大きくする必要があ り，館山付近では方向によつて構造がかなり変化していると考えられる.

\section{$\S 4$. 議 論}

求められた南関東の構造について, 既存の資料との関係などを述べる.

すでに述べたごとく，今回の資料は房総を除いて地震波速度変化の観測のために得られたの で，構造を求めるにはかなり不十分であり，他の解釈の余地は存在する．ただ，速度に関して いえば，館山，銚子爆破の資料は正逆測 線 とみなすことができ， $6.9 \mathrm{~km} / \mathrm{s}$ 層については大島 爆破の房総側と伊豆側の資料を split profile として求めている。 また，Fig.5 と示されるよ らに，南関東では小さい距離から $6.5 \sim 7.7 \mathrm{~km} / \mathrm{s}$ の大きい見掛速度が得られるが, $6.9 \mathrm{~km} / \mathrm{s}$ 層の傾斜によつて説明される，ただ，爆破点，観測点が少ないため，表層の情報は不足してい る. 爆破地震動研究グループによる関東付近などの過去の測線の構造を参照して, 伊豆方向, 大山・堂平方向の遠方では, $5.5 \mathrm{~km} / \mathrm{s}$ 層が $4 \mathrm{~km}$ の厚さで一様に存在すると仮定した. 伊豆 大島, 館山からの測線の方向は異るが，この仮定で観測走時を説明することができた。

房総半島では, すでに述べたように, 爆破地震動研究グループによつて 1956 年に銚子爆破 が行なわれ, 表層付近を除き深さ約 $2 \mathrm{~km}$ から $4.9 \mathrm{~km} / \mathrm{s}$ 層が約 $2 \mathrm{~km}$ の厚さで $5.6 \mathrm{~km} / \mathrm{s}$ 層 の上に存在する構造が得られている〔爆破地震動研究グループ (1958)]. 測線の場所が異るの で層の厚さはかなり違うが, 速度は似ており本論文の構造の方が資料もらえているのでよいと い党よう。

また, 1971 年伊豆大島, 館山爆破による地震動を爆 破地 震動研究グループが長狭 (NGS) 付近から北東への測線で観測して構造を求めた〔爆 破 地震動研究グループ (1974)】が, 本論 文では資料を追加し，かつ，他の方向への構造とも調和するよう改善してある．房総半島南部 長狭 (NGS) 付近には, 地質図に玄武岩質の嶺岡層群の露頭が示されている. 走時にも, この 付近で offset がみられ，本論文では $5.6,6.9 \mathrm{~km} / \mathrm{s}$ 層の上面の offset で説明した。 また， 今回観測された走時より, 伊豆大島・房総半島間に構造の不連続の存在が推定される.このこ そは海底地形にも示されているといえる。すなわち, 相模トラフの東側には断層的な地形が存 在している. 本論文では, 伊豆大島と伊豆半島は構造的に連続しており, 地形が断層的な海底 下で $5.6,6.0 \mathrm{~km} / \mathrm{s}$ 層が接していると仮定した. 
さらに伊豆大島付近では観測走時を説明するためには, ぞの方向からも $6.9 \mathrm{~km} / \mathrm{s}$ 層が浅く なつていることが必要である，このことは，伊豆大島が玄武岩質の火山であることを考えると 極めて興味深いことである.

他に, 爆破地震動研究グループによる関東西部, 東経 $139^{\circ}$ 線に沿つた紫雲寺・河津爆破の 測線の構造がある〔堀田他 (1964)]. この構造では, 伊豆に向つて $6.0 \mathrm{~km} / \mathrm{s}$ 層が厚くなり, $6.8 \mathrm{~km} / \mathrm{s}$ 層が薄くなつており, $6.8 \mathrm{~km} / \mathrm{s}$ 層の上面の傾斜は $1.5^{\circ}$ である. 伊豆は測線の南端 で資料は不十分であるが，単純に延長した $6.8 \mathrm{~km} / \mathrm{s}$ 層の上面の深さは $20 \mathrm{~km}$ をこえている. 本論文の伊豆方向の測線では, 浮橋 $(\mathrm{UKH})$ 付近で $6.9 \mathrm{~km} / \mathrm{s}$ 層上面の深さは約 $15 \mathrm{~km}$ であ り, 北西へ向つて深くなつている. $139^{\circ} \mathrm{E}$ 線とほぼ平行の大島から堂平方向では $6.9 \mathrm{~km} / \mathrm{s}$ 層 は北へ向つて浅くなつている，これらの傾向は, $139^{\circ} \mathrm{E}$ 線の構造の傾向と似ているが傾斜は大 きい.

さらに西の中部地方をほぼ南北に縦断した渥美・能登測線下の構造は, $6.0 \mathrm{~km} / \mathrm{s}$ 層が厚く, 玄武岩質層はないか，うすいと求められている〔AOKI et al. (1972)〕が，伊豆方向への構造 は定性的には調和的である。ただ，Fossa Magna，静岡・糸魚川構造線が介在して複雑に構 造が変化している可能性があるので, 関係づける意味はうすいとも考えられる.

関東地方のやや大規模の地震探査による構造としては, 石油資源開発株式会社の資料を使つ て石井基裕がまとめた論文がある〔石井基裕 (1962)]. 主として関東平野の基盤を論じた論文 であるが，南関東の浅部構造の情報はほとんど含まれていない，基盤の速度は，九十九里浜付 近の測線の南西部で $4.6 \sim 4.9 \mathrm{~km} / \mathrm{s}$, 浅部では $1.68,1.84,2.10,2.50 \mathrm{~km} / \mathrm{s}$ の層が約 $2.5 \mathrm{~km}$ の厚さで存在し, 北東へ向つて浅くなつている. 本論文の浅部構造は, 地震探査によるほど詳 しくないが，調和的といえる，上記の基盤の速度，関東平野の谷田部，飯能間の測線下のそれ は $5.0 \sim 5.8 \mathrm{~km} / \mathrm{s}$ とかなりの幅があるが，本論文の房総で得られた值は，ぞれを基盤とする かによるが矛盾していないといえよう。

\section{§5. 結論}

地震波速度変化観測のための大島, 館山両爆破による地震動の観測資料から南関東地域の地 壳構造を求めた. 両爆破点から 3 方向, 計 6 方向に対して一応, 観測走時を説明できる構造を 求めることができた。ここに得られた大局的な構造の特徵についてまとめる.

1）房総半島では, $5.6 \mathrm{~km} / \mathrm{s}$ 層の上飞低速度の層がかなり厚く存在している.

2) 大島・房総間では或る種の構造の不連続が存在する可能性があり，本論文では仮に海底 地形の断層的な場所の下で $5.6 \mathrm{~km} / \mathrm{s}$ 層と $6.0 \mathrm{~km} / \mathrm{s}$ 層が接しているとした. 
3) 房総半島では $5.6 \mathrm{~km} / \mathrm{s}$ 層が直接 $6.9 \mathrm{~km} / \mathrm{s}$ 層の上に存在し， $6.0 \mathrm{~km} / \mathrm{s}$ 層はないか, 薄 い.

4) 長狭 (NGS) 付近では, $5.6 \mathrm{~km} / \mathrm{s}$ 層, $6.9 \mathrm{~km} / \mathrm{s}$ 層とも, その上面に offset が存在す る可能性がある.

5) 大島から伊豆へかけては, $6.0 \mathrm{~km} / \mathrm{s}$ 層は浅い.

6) $6.9 \mathrm{~km} / \mathrm{s}$ 層は, 両爆破点から房総方向, 堂平方向に浅くなつており，伊豆方向には深 くなつている。

7）大島付近では, どの方向からも $6.9 \mathrm{~km} / \mathrm{s}$ 層がかなり浅くなつている.

本論文で得られた地殼構造は, 用いた資料が別の目的の実験によつて得られたもので, 地殼 構造を求めるのに十分な資料ではないが，南関東の地殼構造の情報は少ないので，この地域の 震源決定などに貢献し得ると考える.いうまでもなく, この地殼構造は, 微小地震の観測資料, 今後の爆破地震動観測資料によつて改善されるのが望ましい.

最後に，貴重な資料を提供された伊豆大島，館山爆破の観測に参加された方々，爆破地震動 研究グループの方々に深く感謝致します.

\section{文献}

Aoki, H., T. Tada, Y. Sasaki, T. Ooida, I. Muramatsu, H. Shimamura and I. Furuya, 1972, Crustal Structure in the Profile across Central Japan as Derived from Explosion Seismic Observations, J. Phys. Earth, 20, 197-224.

浅野周三・一ノ瀬洋一郎・是沢定之・長谷川功・飯塚 進・鈴木宏芳, 1976, 館山爆破による南関東の地 震波速度变化の観測, 第 509 回地震研究所談話会.

爆破地震動研究グループ, 1958, 銚子爆破地震動観測結果報告, 爆破地震動研究グループ会報, 16号, 10 -22,

爆破地震動研究グループ, 1974, 大島・館山爆破から得られた房総半島南部の構造, 昭和 49 年度地震学 会秋季大会講演予稿集, 49 .

堀田 宏・村内必典・宇佐美竜夫・嶋悦三・本谷義信・浅沼俊夫, 1964, 爆破地震動観測に上る本州中央 部を南北に横断する測線上の地殼構造 第 2 部 地殼構造, 地震 $2,17,201-209$.

石井基裕, 1962, 関東平野の基盤, 石油技術協会誌, 27, 615-640.

地震波速度変化研究グループ，1975，爆破地震による地震波速度の時間的变化に関する研究，第 1 部 観 湘報告, 地質調查所報告, 254, 1-33.

田中康裕・清野政明・田沢堅太郎・赤羽俊郎，1969，伊豆大島の地震波速度と地下構造について，火山 $2,14,84-96$. 